\title{
FAKTOR PSIKOLOGIS YANG MEMPENGARUHI PERILAKU MEROKOK PADA REMAJA
}

\author{
Dwi Kencana Wulan \\ Jurusan Psikologi, Faculty of Humanities, BINUS University \\ Jln. Kemanggisan Ilir III no 45, Kemanggisan - Palmerah, Jakarta Barat 11480 \\ kencana.wulan@gmail.com
}

\begin{abstract}
Smoking behavior can be classified as the cause of danger deaseas, both for smokers and for others around them. Smoking is shown to be associated with 25 types of disease that is deadly dangerous, such as lung cancer and coronary heart disease. Every year, deaths caused by smoking increas, but the number of smokers also increases. However, the beginning of a person's age smoking is getting younger. Teenagers reach a high figure as the beginning of a person's age smoking. The reasons for teenagers to smoke tend to be psychosocial. Researcher wants to know what factors play a role in smoking behavior in adolescents. The research method used is descriptive research, that aims to obtain an overview of the factors that play a role in smoking behavior in adolescents. The characteristics of samples: 11-18 years old, still smoking at the time of data retrieval. A measuring tool used is based on the concept of adolescent development from Hurlock. Obtained result is the most instrumental factor is the environment or context of the adolescent. $48 \%$ of respondents stating that, with $24 \%$ seeing friends smoke, 10.7\% see the smoking behavior of parents (father) and $6.6 \%$ see the smoking behavior of siblings. Second is the teenagers' desire to know the taste of cigarettes (28\%). Then $13.3 \%$ of respondents said the affective factor of cigarette smoking plays a role in their behavior. Next is a factor of image formation (10.7\%), with $8 \%$ of respondents who felt a mature image and show maturity by smoking. At the age of early adolescence (11-15 years) who were most responsible factor is to know the taste of cigarettes while in the middle adolescents (15-18 years) the most dominant factor is to see a friend smoking.
\end{abstract}

Keywords: psychological factor, smoking behavior, adolescence

\begin{abstract}
ABSTRAK
Perilaku merokok tergolong dalam perilaku yang dapat membahayakan kesehatan, baik bagi perokok maupun bagi orang lain di sekitarnya. Merokok terbukti berhubungan dengan 25 jenis penyakit berbahaya yang bersifat mematikan, antara lain kanker paru-paru dan jantung koroner. Setiap tahun, angka kematian yang disebabkan rokok semakin bertambah, namun jumlah perokok juga bertambah, bahkan usia seseorang merokok juga semakin muda. Remaja mencapai angka yang tinggi sebagai usia awal seseorang merokok. Alasan remaja merokok cenderung bersifat psikososial. Peneliti ingin mengetahui faktor apa saja yang berperan dalam perilaku merokok pada remaja. Metode penelitian yang digunakan adalah metode penelitian deskriptif yang bertujuan untuk memperoleh gambaran mengenai faktor yang berperan dalam perilaku merokok pada remaja. Sampel penelitian memiliki karakteristik: berusia 11-18 tahun, masih merokok pada saat dilakukan pengambilan data. Alat ukur yang digunakan disusun berdasarkan konsep perkembangan remaja dari Hurlock. Didapatkan hasil yaitu faktor yang paling berperan adalah lingkungan atau konteks remaja; 48\% responden yang menyatakan hal tersebut, dengan 24\% karena melihat teman teman merokok, 10,7\% melihat perilaku merokok orang tua (ayah), dan 6,6\% melihat perilaku merokok saudara kandung. Kedua adalah keinginan remaja untuk mengetahui rasa rokok (24\%). Kemudian, 13,3\% responden menyatakan faktor afektif dari rokok berperan dalam perilaku merokok mereka. Selanjutnya adalah faktor pembentukan image (10,7\%), dengan 8\% responden yang merasa memiliki image dewasa dan menunjukkan kematangan dengan merokok. Pada usia remaja awal (11-15 tahun) yang paling berperan adalah faktor ingin mengetahui rasa rokok, sedangkan pada remaja tengah (15-18 tahun) faktor yang paling dominan adalah melihat teman merokok.
\end{abstract}

Kata kunci: faktor psikologis, perilaku merokok, remaja 


\section{PENDAHULUAN}

Dalam kehidupan sehari-hari sering kali kita menjumpai orang yang merokok di sekitar kita, baik di kantor, di pasar, di tempat umum, di lingkungan sekolah bahkan di rumah kita sendiri. Merokok adalah perilaku yang sangat merugikan bagi kesehatan dan kelangsungan hidup manusia. Kebiasaan merokok bukan hanya merugikan si perokok tetapi juga merugikan orang-orang di sekitarnya yang turut menghisap asap rokok yang dihembuskan si perokok. Angka kesakitan dan kematian yang disebabkan oleh merokok meningkat di seluruh dunia, terutama di negara-negara berkembang (M. Ayus Astoni \& Mohammad Zulkarnain, 1998). Pada tahun 1990-an, terdapat 3 juta kematian per tahun yang disebabkan oleh merokok. Dua juta diantaranya terjadi di negara-negara maju dan 1 juta sisanya terjadi di negara-negara berkembang seperti di Indonesia (infokes.com, Desember 2003). Di Amerika angka kematian penduduk akibat merokok adalah 701 per tahun (M. Ayus Astoni \& Mohammad Zulkarnain 1998). Sedangkan di Indonesia, tingkat kematian akibat kebiasan merokok telah mencapai 57.000 orang setiap tahunnya. Jika pola ini terus berlanjut maka diperkirakan pada tahun 2030 tingkat kematian di dunia akibat konsumsi tembakau akan mencapai 10.000 orang per tahun, dan sekitar 70\% terjadi di negara-negara berkembang termasuk Indonesia (Detik Health, Desember 2003).

Telah dibuktikan bahwa perilaku merokok berhubungan dengan sekitar 25 jenis penyakit pada manusia. Data menunjukkan bahwa merokok menjadi penyebab dari 87\% kematian karena kanker paru-paru, 82\% kematian karena bronkitis kronis dan emfisema, 21\% kematian karena jantung koroner dan $18 \%$ karena stroke. Selain itu, merokok berisiko untuk menimbulkan penyakit kanker mulut, tenggorokan, pankreas, kandung kencing, ulkus peptikum dan lain-lain (M. Ayus Astoni \& Mohammad Zulkarnain, 1998). Rokok juga dapat menimbulkan gangguan kehamilan dan janin, misalnya dapat terjadi keguguran, komplikasi kehamilan, bayi lahir dengan berat badan rendah, penyakit jangka panjang pada bayi (asma dan autisme) serta kelainan perilaku dan kemampuan belajar (perilaku impulsif, kesulitan perhatian dan konsentrasi) (SMOKE, Buku Panduan Ampuh untuk Berhenti Merokok, 2002).

Walaupun demikian jumlah orang yang merokok semakin bertambah, terutama di negaranegara berkembang. Berdasarkan data yang diperoleh dari WHO, bahwa dewasa ini terdapat sekitar 1,1 milyar perokok di seluruh dunia, dimana 300 juta di antaranya terdapat di negara maju, yang terdiri dari 200 juta perokok pria dan 100 juta perokok wanita. Jadi di negara berkembang jumlah perokok hampir 3 kali lipat daripada negara maju, yaitu sekitar 800 juta orang, yang terdiri dari 700 juta perokok pria dan 100 juta perokok wanita (M. Ayus Astoni \& Mohammad Zulkarnain, 1998). Sementara laporan dari WHO tahun 1983 menyebutkan jumlah perokok meningkat 2,1\% per tahun di negara berkembang, sedangkan di negara maju angka ini menurun sekitar 1,1\% per tahun (Kompas, Senin 30 Juni 2003). Data survei Kesehatan Nasional tahun 2001 menunjukkan bahwa 54,5\% laki-laki dan 1,2\% perempuan Indonesia berusia lebih dari 10 tahun merupakan perokok aktif (Detik Health, Desember 2003). Serta berdasarkan hasil Survei Sosial Ekonomi Daerah tahun 2003, 24,94\% penduduk Bandung berusia lebih dari 10 tahun merupakan perokok yang merokok setiap hari dan 5,30\% menyatakan kadang-kadang merokok.

Hal yang memprihatinkan adalah usia mulai merokok yang setiap tahun semakin muda. Di Amerika serikat, lebih kurang 10\% dari penduduk mulai terbiasa merokok pada saat mereka berumur 10 tahun, 65\% perokok mulai kecanduan merokok pada saat mereka berada di sekolah menengah. Sedangkan di Indonesia berdasarkan Survei Kesehatan Rumah Tangga 1995, kebiasaan merokok penduduk sudah dimulai pada usia remaja, dimana 53,2\% dari mereka yang merokok memulai perilaku merokoknya pada usia 15-19 tahun. Bahkan sebanyak 0,55\% dari mereka telah mulai merokok pada usia 5-9 tahun, suatu usia yang sangat muda (M. Ayus Astoni \& Mohammad Zulkarnain, 1998). Pada tahun 2001, di kota Bandung, 26,48\% dari penduduk memulai perilaku merokoknya di usia 10-17 tahun dan angka ini meningkat setahun kemudian, yaitu menjadi 43,42\%. 
Terlihat dari data di atas bahwa remaja mencapai angka yang cukup tinggi sebagai usia awal mula seseorang merokok. Periode remaja merupakan salah satu tahap perkembangan yang penting dalam rentang kehidupan manusia. Menurut Hall, remaja adalah suatu periode kehidupan manusia yang diliputi badai dan stres dan dibebani oleh konflik dan gejolak emosi. Masa remaja memiliki karakteristik tersendiri yang membedakannya dengan periode perkembangan lainnya, antara lain masa remaja merupakan periode peralihan dari masa anak menuju masa dewasa, masa remaja merupakan suatu periode terjadinya banyak perubahan, yaitu perubahan bilogis, perubahan kognitif dan perubahan status sosial. Senang melakukan hal-hal yang berisiko merupakan salah satu ciri remaja, bagi mereka hal tersebut memberikan pengalaman baru dan pengalaman yang hebat, sehingga pada usia ini remaja sering terkait dengan perilaku-perilaku bermasalah salah satunya perilaku merokok. Remaja tidak terlepas dari konteks yang sangat berpengaruh terhadap perilaku dan keputusan yang diambil oleh remaja selama periode perkembangannya, konteks tersebut, yaitu keluarga, teman sebaya, lingkungan sekolah serta lingkungan tempat tinggal remaja. Remaja merupakan periode yang menjadi "ambang pintu" ke periode dewasa, sehingga remaja mulai mencoba untuk bergaya dan bertingkah laku seperti layaknya orang dewasa, salah satu tingkah laku yang diikuti adalah merokok. Berdasarkan karakteristik yang disebutkan di atas membuat remaja menjadi salah satu sasaran yang “empuk" bagi para perodusen rokok. Merokok merupakan salah satu tingkah laku bermasalah yang sering dialami oleh remaja. Tingkah laku ini tergolong dalam tingkah laku yang bermasalah karena merokok adalah perilaku yang seharusnya dilakukan orang dewasa bukan remaja.

Motivasi para remaja untuk merokok umumnya karena faktor psikososial antara lain karena ikut-ikutan, mencontoh orang tua dan saudara kandung, ikut mencontoh teman sebaya, ingin disebut dewasa, coba-coba dan lain-lain (M Ayus Astoni, Mohammad Zulkarnain, 1998). Bagi remaja rokok adalah passport untuk mendapatkan identitas yang populer, mengikuti trend/fashion dan identitas yang "sulit” (Barbara Lloyd and Kevin Lucas, 1998). Pada awal abad 20-an, sebelum seorang remaja pria dianggap dewasa maka dia dituntut untuk merokok, sejak saat itu merokok akhirnya menjadi jalan yang harus dilewati sebelum seorang remaja pria diterima sebagai orang dewasa. Dalam kehidupan sehari-hari, budaya seperti ini muncul dalam bentuk penyebutan "banci" untuk remaja pria yang tidak merokok. Hal ini jelas menekan para remaja yang tidak merokok secara psikologis, akhirnya mereka menjadi luluh dan merokok. Sedangkan pada remaja wanita salah satu alasan merokok adalah untuk menjaga berat badan agar tetap ideal. Remaja biasanya membentuk kelompok-kelompok atau gank, tanpa disadari terbentuk norma untuk diterima menjadi anggota kelompok maka remaja tersebut harus merokok (SMOKE, Buku Panduan Ampuh untuk Berhenti Merokok, 2002). Selain itu, lingkungan keluarga seperti struktur keluarga dan pola asuh orang tua juga dapat menjadi alasan remaja untuk merokok, hasil penelitian Sussex menunjukan bahwa terdapat hubungan yang signifikan antara orang tua dan saudara yang merokok dengan munculnya perilaku merokok pada remaja (Barbara Lloyd and Kevin Lucas, 1998).

Jumlah perokok di kalangan remaja yang semakin meningkat diharapkan akan berkurang. Berdasarkan beberapa fenomena yang diungkapkan di atas, aspek psikologi merupakan salah satu faktor yang berperan penting terhadap munculnya perilaku merokok pada remaja yang akhirnya akan menjadi suatu kebiasaan dan kecanduan terhadap rokok. Dapat dipastikan bahwa setiap individu berbeda-beda, sehingga alasan atau faktor yang menjadi penyebab munculnya perilaku merokok juga akan berbeda pada setiap remaja. Kebiasaan merokok harus segera dihentikan, salah satunya dapat dilakukan dengan pencegahan terhadap perilaku merokok yang dapat dimulai pada usia remaja. Penghentian ini menjadi cukup sulit karena di Indonesia belum banyak terdapat penelitian yang mendasar tentang faktor-faktor yang mempengaruhi perilaku merokok serta faktor apa yang paling dominan, terutama pada remaja yaitu usia yang menjadi awal mula seseorang merokok. Oleh karena itu, peneliti tertarik untuk mengetahui dengan jelas faktor-faktor yang berperan dalam perilaku merokok pada remaja (Taylor, 1995). Jumlah penelitian tentang merokok dan kesehatan masih sangat sedikit di Indonesia sehingga banyak dokter dan ahli kesehatan menggunakan literatur dari luar negeri untuk merancang pendidikan kesehatan (Tjandra Yoga Aditama, 2002). 
Berdasarkan fenomena yang telah diuraikan mengenai perilaku merokok pada remaja, maka peneliti ingin mengetahui: faktor-faktor yang berperan dalam perilaku merokok pada remaja dan faktor apa yang paling dominan.

\section{METODE PENELITIAN}

Rancangan penelitian yang digunakan adalah merupakan rancangan penelitian noneksperimental dan metode yang digunakan adalah metode penelitian deskriptif. Metode penelitian deskriptif adalah tipe penelitian ini didasarkan pada pertanyaan dasar: bagaimana (Gulo, 2003). Penelitian deskriptif ini dilakukan peneliti untuk memperoleh gambaran mengenai faktor-faktor yang berperan dalam perilaku merokok pada remaja. Metode penelitian deskriptif dimaksudkan untuk melakukan pengukuran yang cermat terhadap fenomena sosial tertentu, dalam hal ini fenomena merokok, dengan cara mengembangkan konsep dan menghimpun fakta tanpa melakukan pegujian hipotesis. Tujuan utama dari penelitian deskriptif adalah membuat gambaran atau deskripsi tentang suatu keadaan yaitu faktor-faktor yang berperan dalam perilaku merokok pada remaja, secara objektif.

Dalam penelitian deskriptif ini peneliti menggunakan teknik penelitian survei. Survei merupakan suatu cara penelitian deskriptif yang mengambil sampel dari suatu populasi dan menggunakan kuesioner sebagai alat pengumpulan data (Masri Singarimbun,1998).

Variabel penelitian adalah faktor-faktor yang berperan dalam perilaku merokok pada remaja. Definisi konseptual faktor atau hal yang menentukan perilaku; dalam penelitian ini adalah perilaku merokok (behavior determinant), yaitu segala hal atau variabel apapun yang merupakan kondisi pendahulu yang diperlukan untuk menyebabkan tingkah laku merokok (Tolman, dalam kamus lengkap Psikologi;1999). Definisi operasional, yaitu segala hal atau faktor yang terjaring dari kuesioner atau alat ukur yang dibuat oleh peneliti berdasarkan kosep perkembangan remaja.

Dalam penelitian ini akan digunakan sampel dengan karakteristik: remaja merokok berusia 11-18 tahun. Rentang usia tersebut merupakan usia periode perkembangan remaja yang merupakan target penelitian, serta sesuai dengan fenomena bahwa usia remaja menjadi awal mula munculnya perilaku merokok pada diri seseorang. Selain itu, masih merokok sampai saat dilakukan penelitian. Sesuai dengan tujuan dari penelitian untuk mendapatkan faktor-faktor yang berperan dalam perilaku merokok pada remaja, sehingga targetnya adalah remaja yang merokok dengan tidak membahas remaja yang sebelumnya pernah merokok karena akan terdapat kemungkinan adanya data-data yang kurang berhubungan dengan tujuan penelitian.

Proses pengambilan sampel dalam penelitian ini menggunakan sampling purposive (atau dikenal juga dengan sampling pertimbangan), yaitu proses pengambilan sampel yang dilakukan berdasarkan kepada pertimbangan tertentu yang diambil berdasarkan tujuan penelitian. Cara pengambilan sampel ini sering dinamakan sampel non peluang karena pada waktu sampel diambil dari populasi, peluang tidak diikutsertakan. Ketelitian dan kerepresentatifan sampel non peluang tidak dapat ditaksir dan akibatnya tidak mungkin menggeneralisasikan hasil sampel terhadap populasi (Prof. DR. Sudjana, MA, M.Sc. 1996).

Dasar pertimbangan penggunaan teknik pengambilan sampel ini adalah bahwa peneliti tidak memiliki gambaran mengenai jumlah populasi secara tepat. Namun demikian, sampel tetap dipilih dengan pertimbangan karakteristik-karakteristik tertentu yang telah ditetapkan oleh peneliti sesuai dengan tujuan penelitian, yaitu mendapatkan faktor-faktor yang berperan dalam perilaku merokok pada remaja. Besarnya jumlah sampel tidak terbatas, melainkan tergantung pada sebanyak apa jumlah sampel yang nantinya diperoleh peneliti. Ini sesuai dengan teknik sampling yang purposive, yang tidak mensyaratkan jumlah tertentu dalam besar sampelnya. Untuk penelitian ini, jumlah sampel yang berhasil diperoleh peneliti adalah 75 orang. 
Pengolahan data dilakukan dengan menggunakan statistika deskriptif. Statistika deskriptif adalah statistik yang berfungsi untuk mendeskripsikan atau memberi gambaran terhadap obyek yang diteliti melalui data sampel atau populasi sebagaimana adanya, tanpa melakukan analisis dan membuat kesimpulan yang berlaku untuk umum. Statistika deskriptif yang akan digunakan adalah, tabel distribusi frekuensi untuk penyajian data-data yang akan didapatkan, modus dan persentase (\%) untuk melihat data yang paling populer yaitu faktor yang paling dominan.

\section{HASIL DAN PEMBAHASAN}

Seluruh responden penelitian ini berjumlah 75 orang, dengan 26 orang tergolong dalam usia remaja awal (usia SMP) dan 49 orang tergolong dalam usia remaja pertengahan (usia SMU). Hasil yang diperoleh dari penelitian ini adalah berupa gambaran mengenai faktor-faktor yang berperan dalam perilaku merokok pada remaja, disertai dengan data-data tambahan yang dapat digunakan untuk memperkuat data utama dalam pembahasan.

\section{Hasil Penelitian Mengenai Faktor-faktor yang Berperan dalam Perilaku Merokok pada Remaja}

Berikut ini penyajian data faktor-faktor yang berperan dalam perilaku merokok pada remaja.

Tabel 1 Gambaran faktor-faktor yang berperan dalam perilaku merokok pada remaja (seluruh responden)

\begin{tabular}{|c|c|c|}
\hline Faktor-faktor & Frekuensi & Persentase \\
\hline \multicolumn{3}{|l|}{ Konteks/lingkungan remaja } \\
\hline \multicolumn{3}{|l|}{ Keluarga (family) } \\
\hline Karena melihat orang tua merokok & 8 orang & $10,7 \%$ \\
\hline Karena melihat saudara kandung merokok & 5 orang & $6,6 \%$ \\
\hline \multicolumn{3}{|l|}{ Teman Sebaya (peer) } \\
\hline Karena melihat teman dekat saya merokok & 18 orang & $24 \%$ \\
\hline Karena disuruh teman saya merokok & 3 orang & $4 \%$ \\
\hline Karena dipaksa teman saya merokok & 2 orang & $2,7 \%$ \\
\hline \multicolumn{3}{|l|}{ Lingkungan sekolah } \\
\hline \multicolumn{3}{|l|}{ Karena melihat guru saya merokok di sekolah } \\
\hline \multicolumn{3}{|l|}{ Lingkungan rumah } \\
\hline \multicolumn{3}{|l|}{ Karena melihat orang dewasa disekitar saya merokok } \\
\hline \multicolumn{3}{|l|}{ Karena melihat iklan rokok di televisi } \\
\hline \multicolumn{3}{|l|}{ Faktor afektif dari merokok } \\
\hline \multicolumn{3}{|l|}{ Rokok memberikan kenikmatan } \\
\hline Karena rokok memberi kenikmatan bagi saya & 4 orang & $5,3 \%$ \\
\hline Karena rokok memberikan perasaan tenang untuk saya & 3 orang & $4 \%$ \\
\hline \multicolumn{3}{|l|}{ Karena merokok memberikan suatu tantangan untuk saya } \\
\hline \multicolumn{3}{|l|}{ Rokok dapat mengendalikan stress } \\
\hline Karena menganggap rokok dapat membantu menyelesaikan masalah saya & 2 orang & $2,7 \%$ \\
\hline \multicolumn{3}{|l|}{$\begin{array}{l}\text { Karena merokok dapat membantu saya berkonsentrasi dalam menyelesaikan } \\
\text { tugas-tugas sekolah }\end{array}$} \\
\hline \multicolumn{3}{|l|}{ Body image } \\
\hline Karena ingin menjaga berat badan saya (ingin tetap langsing) & 1 orang & $1,3 \%$ \\
\hline \multicolumn{3}{|l|}{ Merokok dalam pembentukan image dan identitas sosial } \\
\hline \multicolumn{3}{|l|}{ Pembentukan image } \\
\hline Karena ingin terlihat "gaya" & 2 orang & $2,7 \%$ \\
\hline Karena saya ingin terlihat dewasa & 6 orang & $8 \%$ \\
\hline \multicolumn{3}{|l|}{ Karena ingin terlihat mengikuti trend merokok } \\
\hline \multicolumn{3}{|l|}{ Identitas sosial } \\
\hline \multicolumn{3}{|l|}{ Karena saya ingin diterima dalam suatu kelompok } \\
\hline \multicolumn{3}{|l|}{ Karena ingin diterima dalam suatu kelompok yang beranggotakan perokok } \\
\hline Karena ingin mengetahui rasanya rokok & 21 orang & $28 \%$ \\
\hline Jumlah responden & 75 orang & $100 \%$ \\
\hline
\end{tabular}


Rasa ingin tahu yang besar pada remaja merupakan faktor yang paling dominan yang mendorong remaja untuk merokok (28\%). Diikuti oleh lingkungan remaja, dengan pengaruh teman sebaya mencapai persentase yang terbesar, yaitu melihat teman dekat merokok (24\%), disuruh teman merokok (4\%), dan dipaksa teman merokok (2,7\%). Lingkungan keluarga juga menjadi faktor yang cukup dominan. Hal ini dapat dilihat dari $10,7 \%$ responden menyatakan merokok karena melihat orangtua merokok dan 6,6\% responden menyatakan karena melihat saudara kandung merokok. Selanjutnya faktor pembentukan image dari merokok bagi remaja, 8\% dari responden menyatakan ingin memiliki image terlihat dewasa dengan merokok dan $4 \%$ menyatakan ingin terlihat "gaya". Sedangkan faktor afektif dari rokok yaitu, 5,3\% responden menganggap rokok memberikan kenikmatan dan $4 \%$ menganggap rokok memberikan perasaan tenang bagi mereka.

\section{Data di Atas Dalam Bentuk Diagram}

Gambar 2 Diagram Faktor yang Berperan dalam Perilaku Merokok pada Remaja

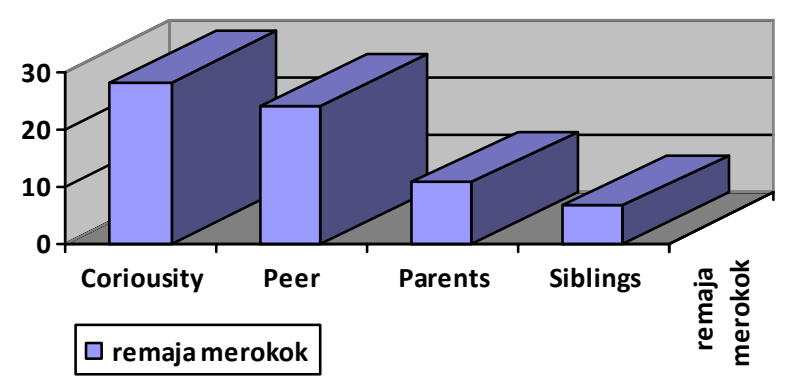

Berdasarkan penelitian ini, didapatkan faktor-faktor yang berperan dalam perilaku merokok pada remaja. Bagi remaja rasa ingin tahu terhadap rokok menjadi faktor paling utama yang mendorong munculnya perilaku merokok. Hal ini ditunjukkan dengan angka 28\% dari responden yang menyatakan hal tersebut. Rasa ingin tahu yang besar pada remaja, dilatarbelakangi oleh keinginan remaja untuk mencoba berbagai macam hal baru. Selanjutnya faktor kedua yang dominan adalah lingkungan atau konteks remaja. Berdasarkan data yang diperoleh, 24\% responden menyatakan faktor lingkungan yang paling berperan adalah teman sebaya yaitu karena melihat perilaku teman yang merokok. Peneliti juga mendapatkan data yang dapat memperkuat data di atas, yaitu hanya 1,3\% responden yang menyatakan tidak memiliki teman dekat yang merokok, hal ini menandakan bahwa pengaruh teman sebaya cukup kuat dalam mendorong munculnya perilaku merokok pada remaja. Pada usia remaja, teman sebaya memiliki peran dan pengaruh yang kuat bagi remaja, terutama dalam hal pembentukan sikap dan perilaku. Salah satu karakteristik remaja adalah ingin bergabung dan menyesuaikan diri dengan suatu kelompok atau gank. Penyesuaian diri tersebut dilakukan dengan cara bertingkah laku yang sama dengan anggota kelompok lainnya. Oleh karena itu, remaja sering kali meniru perilaku merokok temanya karena ingin terlihat sama dengan teman dekatnya. Salah satu tugas perkembangan remaja adalah mencapai hubungan baik dan lebih matang dengan teman sabayanya. Mengikuti perilaku merokok teman sebaya mungkin merupakan salah satu usaha untuk mencapai tugas perkembangannya.

Faktor lingkungan yang dominan selanjutnya adalah lingkungan keluarga, yaitu melihat orangtua merokok (10,7\%) dan melihat saudara kandung merokok (6,6\%). Lingkungan keluarga yang merupakan lingkungan utama remaja juga memberikan contoh pada remaja dalam bertingkah laku, terutama tingkah laku orang-orang dewasa di sekitarnya. Perilaku merokok yang ditiru remaja terutama didapat dari perilaku merokok ayah, karena diperoleh data $40 \%$ responden menyatakan 
memiliki ayah yang merokok dan 10,7\% memiliki ayah dan saudara kandung yang merokok. Faktor dominan selanjutnya adalah pembentukan image dari merokok. Delapan persen responden menyatakan merokok karena ingin dapat terlihat dewasa. Pembentukan image merupakan awal dari pembentukan identitas pada remaja, dimana pembentukan identitas merupakan hal yang penting bagi remaja (smoking in adolescence, 1998). Salah satu minat remaja adalah minat terhadap status simbol. Status simbol merupakan simbol prestise yang menunjukkan bahwa orang yang memilikinya akan mempunyai status yang lebih tinggi dalam kelompok. Rokok dijadikan salah satu stastus simbol bagi remaja dengan anggapan merokok adalah perilaku yang menunjukkan kematangan dan melambangkan status hampir dewasa. Sehingga, dengan merokok, mereka merasa mendapatkan image dewasa. Masa remaja merupakan ambang pintu masa dewasa. Hal ini membuat remaja sering kali memusatkan diri pada perilaku yang dihubungkan dengan status dewasa. Remaja mulai mengikuti perilaku-perilaku orang dewasa yang membuat remaja terjerumus dalam kenikmatan-kenikmatan tabu (bentuk-bentuk perilaku yang dianggap simbolik orang dewasa). Perilaku tersebut antara lain merokok, minumminuman keras, menggunakan obat-obatan terlarang dan terlibat dalam perbuatan seks (Hurlock, 1980). Faktor dominan terakhir yang mendorong remaja untuk merokok adalah faktor afektif dari merokok. Lima koma tiga persen responden menyatakan merokok karena rokok memberikan kenikmatan bagi mereka dan $4 \%$ responden merokok karena rokok memberikan perasaan tenang serta 2,7\% merokok karena rokok dapat membantu menyelesaikan masalah mereka. Kenikmatankenikmatan ini berasal dari zat-zat yang terkandung dalam rokok yang dapat menyebabkan ketergantungan terhadap rokok.

\section{SIMPULAN}

Faktor terbesar yang mendorong remaja untuk merokok adalah faktor keingintahuan remaja akan rasa rokok, kemudian faktor kedua adalah faktor lingkungan atau konteks remaja. Faktor lingkungan yang utama adalah pengaruh teman sebaya yang merokok. Pada usia remaja pengaruh teman sebaya sangatlah kuat, salah satunya dalam pembentukan perilaku merokok. Diikuti meniru perilaku orangtua (ayah) yang merokok dan saudara kandung yang merokok. Selanjutnya, faktor pendorong remaja untuk merokok adalah keinginan untuk mendapatkan image dewasa. Faktor terakhir adalah faktor afektif dari merokok, yaitu rokok dianggap memberikan kenikmatan dan memberikan perasaan tenang. Pada kelompok usia remaja awal, faktor pertama yang paling dominan dalam perilaku merokok adalah adanya keinginan yang besar untuk mengetahui rasanya rokok. Hal ini dialatarbelakangi oleh rasa ingin tahu remaja yang besar dan keinginan untuk mencoba hal-hal baru. Kedua adalah lingkungan/konteks remaja, yang mana faktor keluarga yang paling berperan terutama perilaku merokok ayah dan saudara kandung. Diikuti dengan faktor teman sebaya yang merokok. Faktor ketiga adalah peran rokok dalam pembentukan image, dengan ingin terlihat dewasa yang paling dominan. Terakhir adalah rokok dianggap memberikan kenikmatan bagi remaja.

Sedangkan pada kelompok usia remaja pertengahan, yang menjadi faktor utama yang paling dominan adalah faktor lingkungan/konteks. Konteks remaja yang paling berpengaruh adalah teman sabaya yang merokok. Mereka cenderung mengikuti perilaku merokok teman dekatnya. Selanjutnya pengaruh keluarga, yaitu mereka mengikuti perilaku merokok ayah dan saudara kandung mereka. Faktor kedua yang dominan adalah adanya rasa ingin mengetahui rasa rokok yang sangat besar. Faktor dominan ketiga adalah faktor afektif dari rokok, yaitu kenikamatan-kenikmatan yang diberikan rokok. Faktor afektif tersebut adalah rokok dianggap memberikan perasaan tenang, rokok memberikan kenikmatan, rokok sebagai alat untuk membantu menyelesaikan masalah, dan rokok untuk menjaga berat badan (ingin tetap langsing). Faktor terakhir adalah faktor rokok dalam pembentukan image, yaitu ingin terlihat dewasa dan ingin terlihat "gaya". 
Perilaku merokok juga dapat merujuk pada munculnya keinginan untuk mengkonsumsi zat-zat terlarang. Dalam penelitian ini diperoleh beberapa responden yang memiliki keinginan untuk mengonsumsi zat terlarang, yaitu ganja dan shabu. Penelitian ini mencoba menjaring faktor-faktor yang berperan dalam perilaku merokok pada remaja. Hasil yang diperoleh dapat digunakan oleh orangtua, sekolah, atau orang-orang dewasa di sekitar lingkungan remaja. Untuk mengimbangi rasa ingin tahu remaja yang besar tentang rokok, diharapkan segala pihak yang terlibat selama masa perkembangan remaja dapat memberikan informasi selengkap-lengkapnya mengenai kandungan ataupun dampak buruk dari rokok sehingga remaja dapat memutuskan dengan baik apakah mereka ingin merokok atau tidak. Orang tua yang merokok agar lebih menyadari dan memerhatikan bahwa remaja mengikuti atau meniru perilaku merokok anggota keluarganya dirumah. Pihak sekolah, terutama para guru, diharapkan untuk memberikan contoh yang baik, misalnya tidak merokok di lingkungan sekolah atau di depan siswa. Hal itu akan menyebabkan siswa yang tergolong dalam usia remaja menjadi ingin merokok. Pihak sekolah juga dapat mengadakan program penyuluhan tentang merokok sehingga remaja dapat mengetahui segala informasi mengenai rokok.

\section{DAFTAR PUSTAKA}

Aditama, Tjandra Yoga. (2002). Smoking Problem in Indonesia. Medical Journal of Indonesia. Fakultas Kedokteran Universitas Indonesia.

Astoni, M.A; M. Zulkarnaen. (1999). Pengetahuan, Sikap dan Perilaku Merokok serta Prevalensi Perokok pada Remaja di Kelurahan Marianan Kecamatan Banyuasin I Kabupaten Musi Banyuasin. Jurnal Kedokteran Universitas Sriwijaya.

Desember, 2003. Ada Apa Dengan Merokok?. www. Sekolahindonesia.com.

Caldwell, E.1991. Bagaimana Anda dapat Berhenti Merokok dengan Mudah. Diterjemahkan dari How You Can Stop Smoking oleh Bahri Syamsul S. Jakarta: Gunadi Pratama. 15-19, 33-35.

Chaplin, J.P. (1999). Kamus Lengkap Psikologi. Jakarta: Rajawali Pers.

Corey, G. (1982). Theory and Practice of Counseling and Psychotherapy. $2^{\text {nd }}$ edition. Montesory: Brook/Cole publishing Company.

Detik Health. (2003). Penjelasan atas Peraturan Pemerintah Republik Indonesia Nomor 19 tahun 2003 Tentang Pengamanan Rokok Bagi Kesehatan. www.detik.com.

Gazda, G..M. (1984). Group Counseling A Developemental Approach. $3^{\text {rd }}$ edition. Boston: Allyn \& Bacon, Inc.

Hurlock, Elizabeth. (1980). Psikologi Perkembangan, Suatu Pendekatan Sepanjang Rentang Kehidupan. Edisi kelima. Alih bahasa: Istiwidayanti. Jakarta: Erlangga.

Lloyd, Barbara; Kevin Lucas. (1998). Smoking in Adolescence. London and New York: Routledge.

Margono, B.P. (1996). Usaha Penghentian Merokok. Jur Respir Indo. 16, 118-120.

Santrock, J.W. 2003. Adolescence. $9^{\text {th }}$ Edition. Dallas: McGraw-Hill. . (2002). SMOKE, Buku Panduan Ampuh untuk Berhenti Merokok. Jakarta: Nexx Media.

Steinberg, Laurence. (1996). Adolescence. 4 th Edition. New York: McGraw-Hill. 